\title{
Mineralogical Characterization of Premix Used in the Manufacture of Feed for Poultry and Livestock
}

\author{
Snezana Dević ${ }^{1}$, Mira Cocić ${ }^{2}$, Mihovil Logar ${ }^{3}$, Suzana Erić $^{3} \&$ Nenad Matejević ${ }^{4}$ \\ ${ }^{1}$ IMS Institute, Belgrade, Serbia \\ ${ }^{2}$ Technical Faculty Bor, Serbia \\ ${ }^{3}$ Mining and Geology Faculty, Belgrade, Serbia \\ ${ }^{4}$ Jabuka, Animal Feed Factory, Jabuka, Serbia \\ Correspondence: Snezana Dević, IMS Institute, Bulevar vojvode Mišića 43, 11000 Belgrade, Serbia. Tel: \\ 381-11-2650-322/240. E-mail: snezana.devic@institutims.rs
}

\author{
Received: June 13, 2013 Accepted: August 28, 2013 Online Published: October 15, 2013 \\ doi:10.5539/jas.v5n11p110 \\ URL: http://dx.doi.org/10.5539/jas.v5n11p110
}

\begin{abstract}
One of the basic requirements that must be met in the production of livestock and poultry is a good food for their diet. Premix is an integral part in the food production for poultry and livestock. It is a mixture of organic and inorganic components. Our study has been conducted with a goal to identify minerals in foreign premix for the production of domestic premix and substitution of premix imported. Food with foreign premix has shown good results while raising poultry and livestock. Production of domestic premix with minerals from our area would enable better utilization of domestic resources. Using different methods (DTA, IR, XRD, SEM and EDS) mineralogical characterization of foreign premix has been made. Based on results of mineralogical characterization, minerals in mineral part of foreign producers' premix have been clearly identified. They are Clinoptilolite $(\mathrm{Ca}, \mathrm{K},)_{2-3} \mathrm{Al}_{3}(\mathrm{Al}, \mathrm{Si})_{2} \mathrm{Si}_{13} \mathrm{O}_{36} 12\left(\mathrm{H}_{2} \mathrm{O}\right)$, as primary and minerals Quartz $\left(\mathrm{SiO}_{2}\right)$ and Calcite $\left(\mathrm{CaCO}_{3}\right)$ as secondary. The Clinoptilolite is mineral from zeolite group.
\end{abstract}

Keywords: premix, mineralogical characterization, feed, poultry, livestock, clinoptilolite

\section{Introduction}

Premixes are very important factors in the production of poultry and livestock (Zlatić, 1983). Besides the organic part of premix, inorganic part plays also an important role in premix composition. Qualitative and quantitative content of both parts of premix affect the quality of the food. Domestic and foreign premix, depending on the composition have different effects in feeding hogs (Zivković et al., 2010a; Zivković et al., 2010b). Inorganic part is mineral supplement. Minerals as ingredients in the premix are usually bentonite - montmorilloniet, glauconite, minerals of the zeolite group, limestone and others (Stojiljković et al., 2002). Minerals are biostimulators of growth in poultry and livestock (Vakanjac, 1992). Bentonite, montmorillonit, glauconite and minerals from the group of zeolites have similar structure and ability of absorption. They adsorb and release the water, exchange cations, without destroying the crystal lattice. Cation exchange capacity is the major characteristic of mineral absorbent. Value of Cation exchange capacity "CEC" determines the usage. This feature allows them to be used for removal of mycotoxins as absorbents and to have function of immunostimulator. Mycotoxins are harmful to the health of livestock and poultry. Immunostimulator minerals reinforce the development of cells of the immune system in poultry and livestock. Immune system cells destroy bacteria and viruses (Adamović et al., 2003).

The material examined this paper is a foreign premix. The composition of the organic part premix was known. The organic part consists of Saccharomyces cerevisiae (yeast), vitamin E and related components. The composition of the inorganic part of the premix was unknown. Minerals of inorganic part premix are identified by mineralogical characterization.

\section{Materials and Methods}

Foreign producers' premix is material tested for identification of minerals in mineral addition. Modern methods were used for testing premix. For DTA analysis was used electric furnace - type Adamel (thermocouple Platinum/Platinum-Rhodium). IR Spectrophotometer type Perkin Elmer 597 was used for IR spectrophotometric 
analysis. Sample 1 represents starting premix that has been tested by DTA analysis and IR analysis. The premix has been annealed at $400^{\circ} \mathrm{C}, 600^{\circ} \mathrm{C}$ and $800^{\circ} \mathrm{C}$ with two hours of retention. Process has been repeated four times with constant weight. Samples 2, 3 and 4 represent annealed premixes. Sample 1 (initial premix), sample 2 (premix annealed at $400^{\circ} \mathrm{C}$ ), sample 3 (premix annealed at $600^{\circ} \mathrm{C}$ ) and sample 4 (premix annealed at $800^{\circ} \mathrm{C}$ ) have been tested by X-ray diffraction method. The X-ray diffractogram (XRD) were obtained on Rendgen diffractograf type Philips PW 1710, anticathode copper, wavelength of $\mathrm{CuK} \alpha=1.54178 \AA$. The same samples are tested with electronic microscopy (SEM-EDS analysis). For this analysis, was used electronic microscope JEOL JSM-6610 LV with INCA Energy 350.

\section{Results and Discussion}

Sample 1 differential thermal analysis curve (initial premix) is represented by Figure 1. Curve registers endothermic effect at $100^{\circ} \mathrm{C}$. This effect is consequence of humidity loss in Sample 1. Second registered exothermic effect at interval of $200^{\circ} \mathrm{C}$ to $600^{\circ} \mathrm{C}$ is the consequence of combustion of organic portion of premix. The third endothermic effect on the curve has been registered at $840^{\circ} \mathrm{C}$. This effect has derived from decarbonization of Calcite $\left(\mathrm{CaCO}_{3}\right)$, when it transfers to free $\mathrm{CaO}$ and loses $\mathrm{CO}_{2}$.

Endothermic effect is characteristic for Calcite deriving during heating at interval from $800^{\circ} \mathrm{C}$ to $1000^{\circ} \mathrm{C}$, (Ristić \& Kovačević, 1983; Kulikov et al., 1985; Frye, 1981).

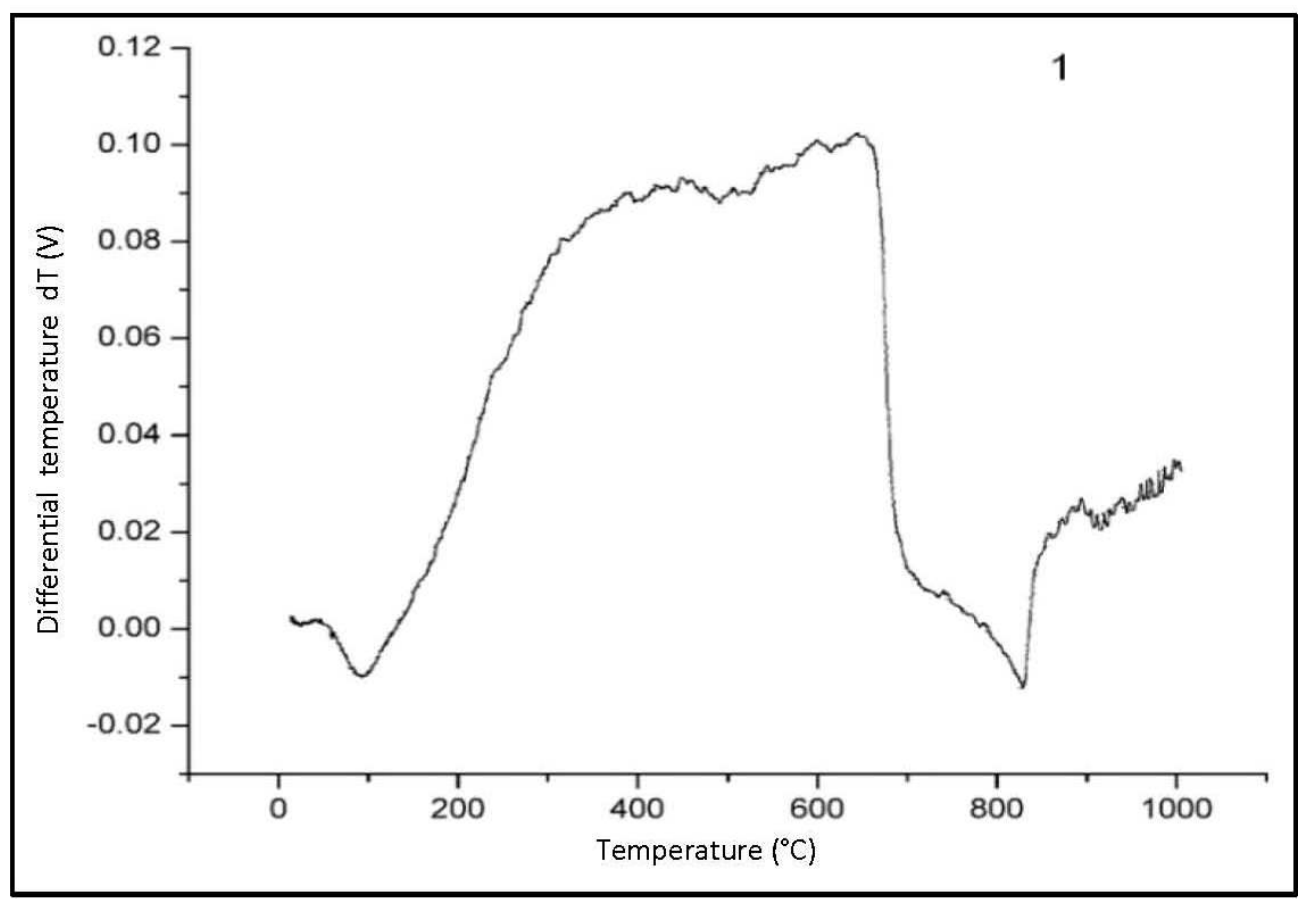

Figure 1. Differential thermal curve of sample 1

Samples 2, 3 and 4 were annealing at different temperatures with constant weight. The highest value (21.44\%) loss on ignition was recorded for sample 4 (sample annealed at $800^{\circ} \mathrm{C}$ ). Image 2 represents Macro set of Sample 1 premix that is not annealed and annealed samples of premix 2, 3 and 4 . 


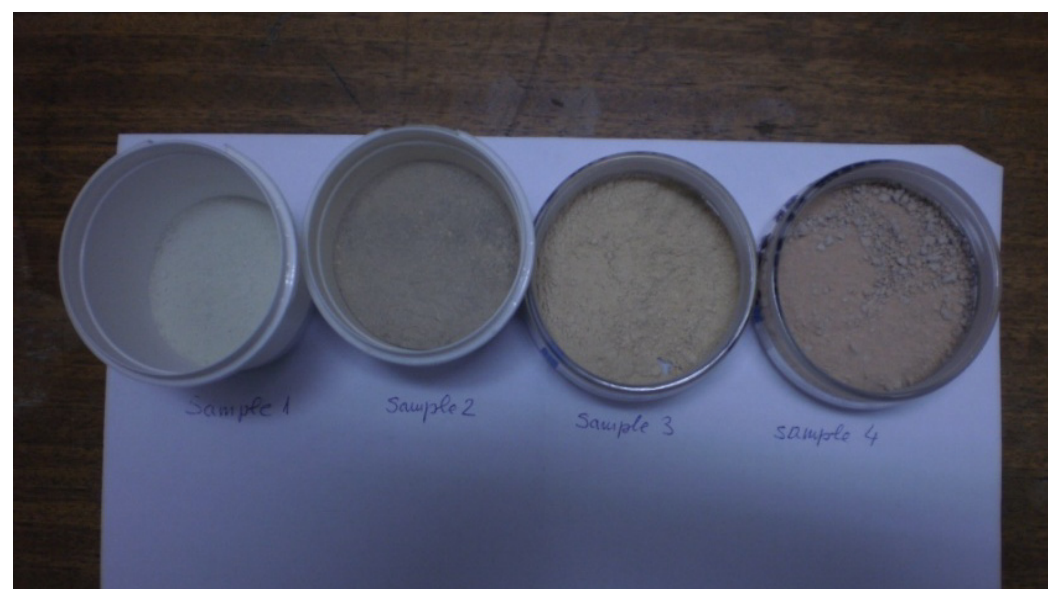

Figure 2. Macro view of the premix (samples 1, 2, 3 and 4)

Annealed samples were macroscopically different in color from the initial premix. Initial Sample 1 was colored light gray and annealed samples different shades of brown.

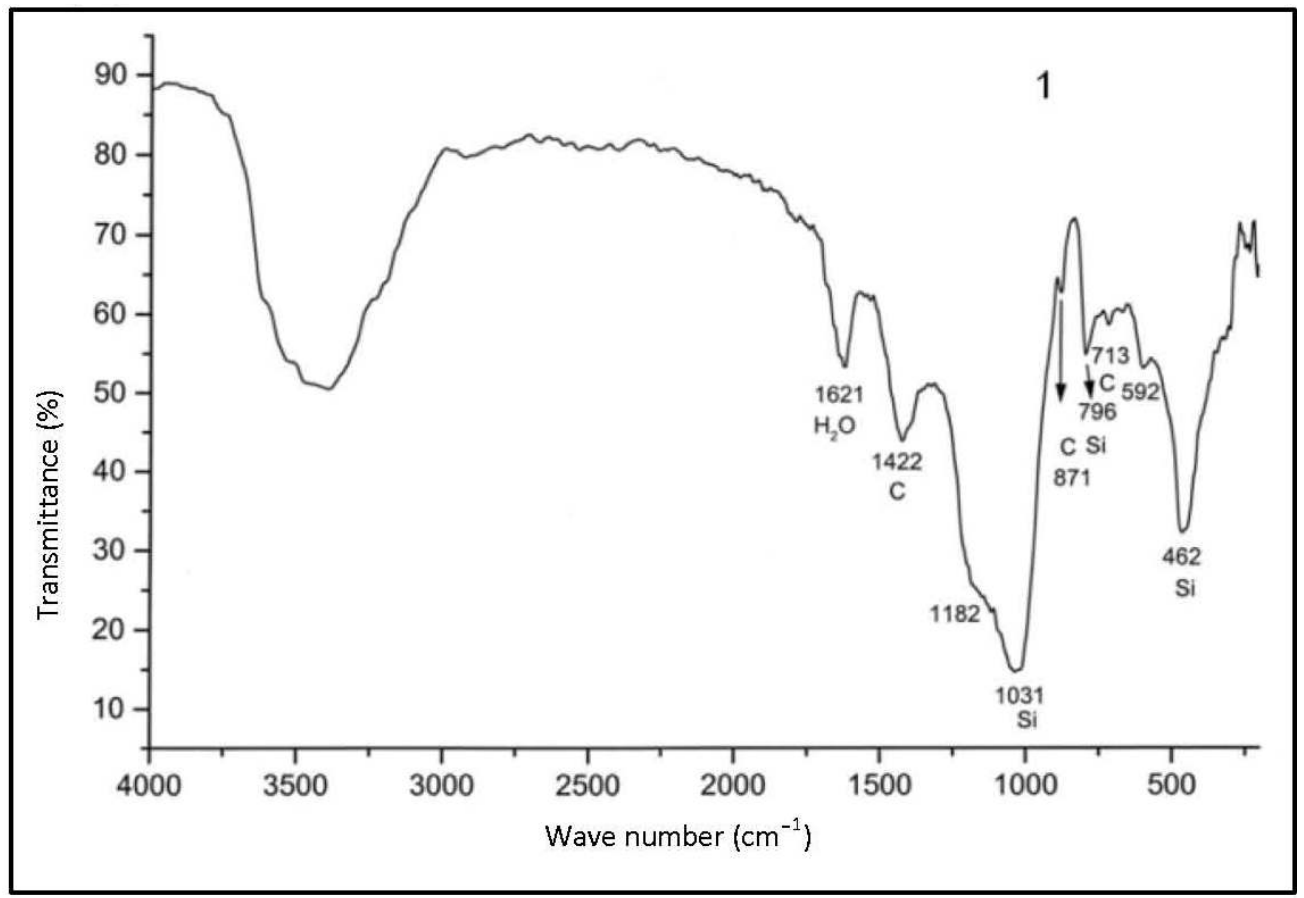

Figure 3. Infrared curve of sample 1

Infrared (IR) curve of the sample 1 (Figure 3) showed the characteristics of the group minerals hydrosilicate. XRD diffractograms of premix 1, 2 and 3 showed the presence of the same mineral phases, but the content of these minerals is different (Figures 4, 5 and 6). In all three samples the dominant mineral was Clinoptilolite $(\mathrm{Ca}, \mathrm{K}$,) ${ }_{2-3} \mathrm{Al}_{3}(\mathrm{Al}, \mathrm{Si}){ }_{2} \mathrm{Si}_{13} \mathrm{O}_{36} 12\left(\mathrm{H}_{2} \mathrm{O}\right)$, that belongs to the group of zeolite. Clinoptilolite is leafy zeolite (Ilic \& Karamata, 1978). Calcite, Quartz and Cristobalite appear next to Clinoptilolite. These minerals are often found with Clinoptilolite (Kerr, 1959). However, Sample 4 was characterized by the presence of amorphous solids, minerals quartz and cristobalite. Calcite was not found in this sample. Calcite has lost $\mathrm{CO}_{2}$ through decarbonization and has been transferred into free $\mathrm{CaO}$. 


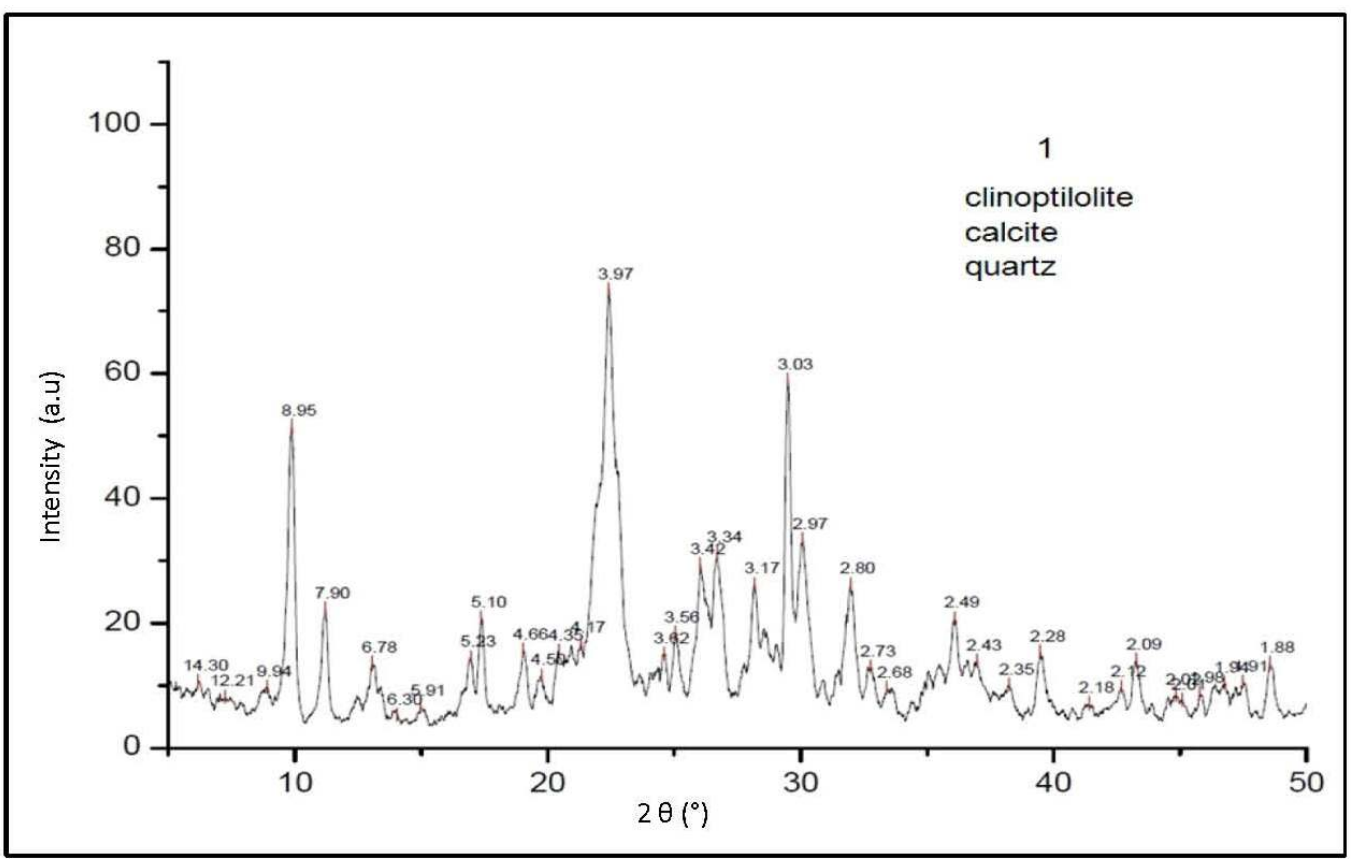

Figure 4. XRD diffractogram of the sample 1

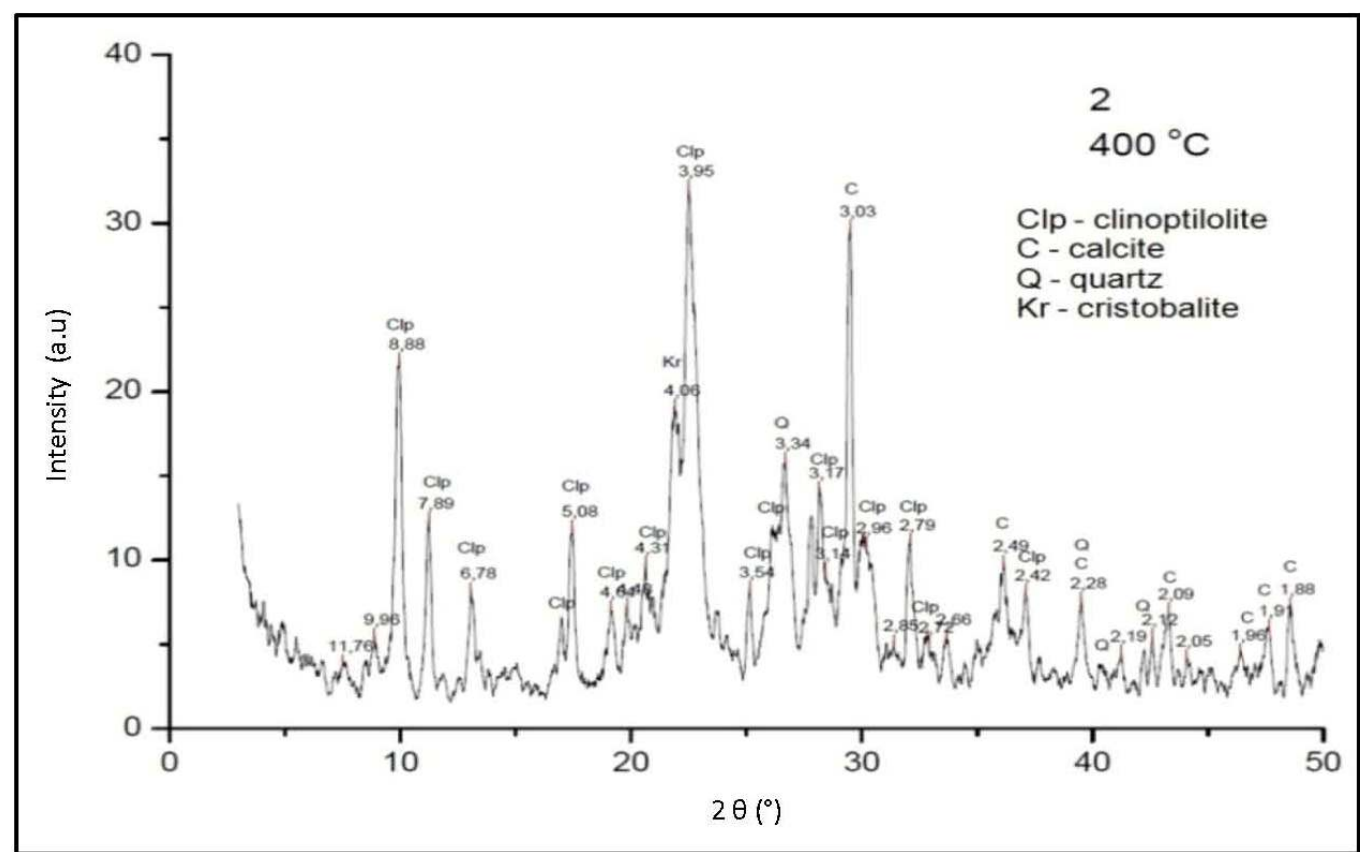

Figure 5. XRD diffractogram of the sample 2 


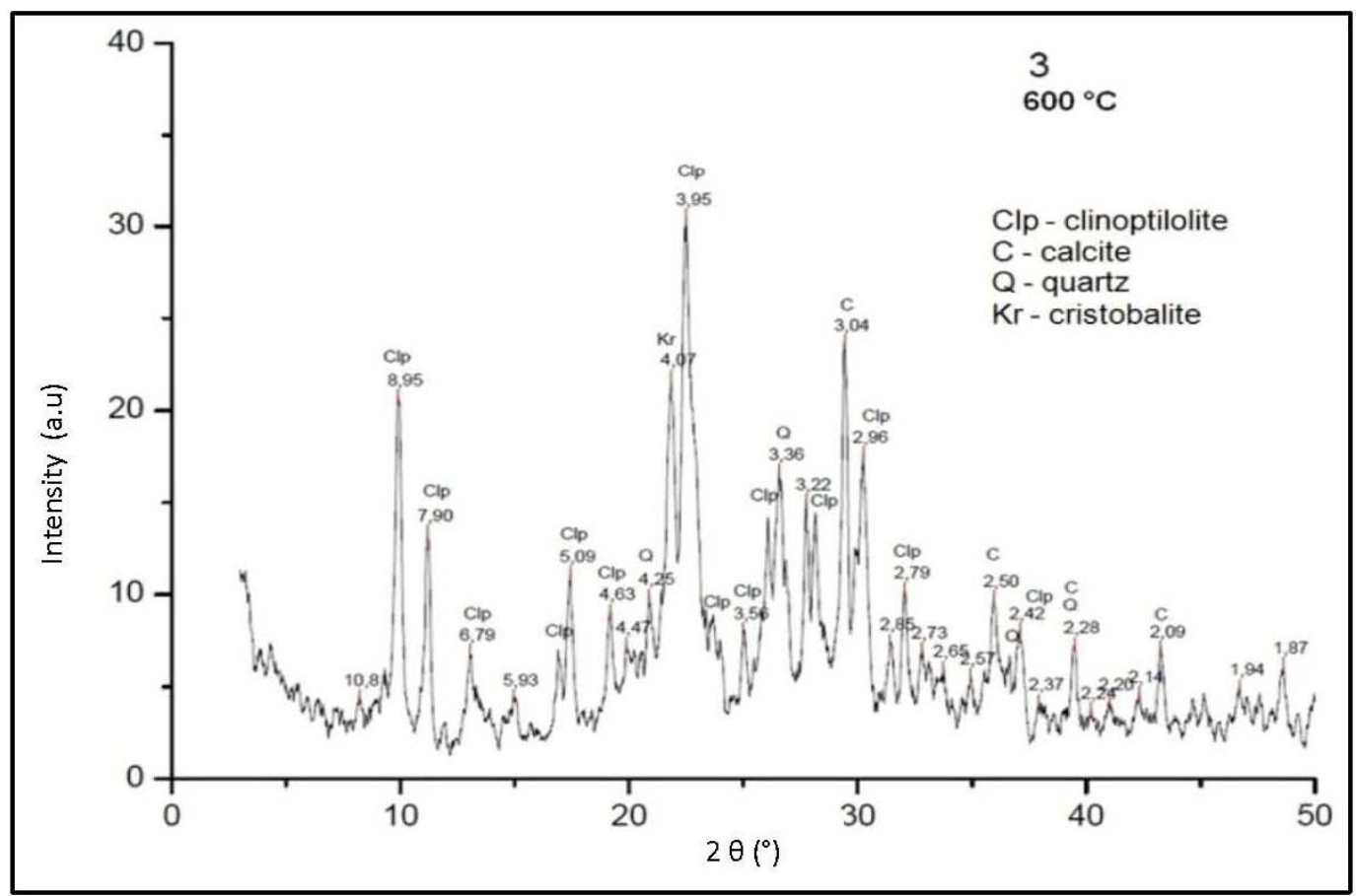

Figure 6. XRD diffractogram of the sample 3

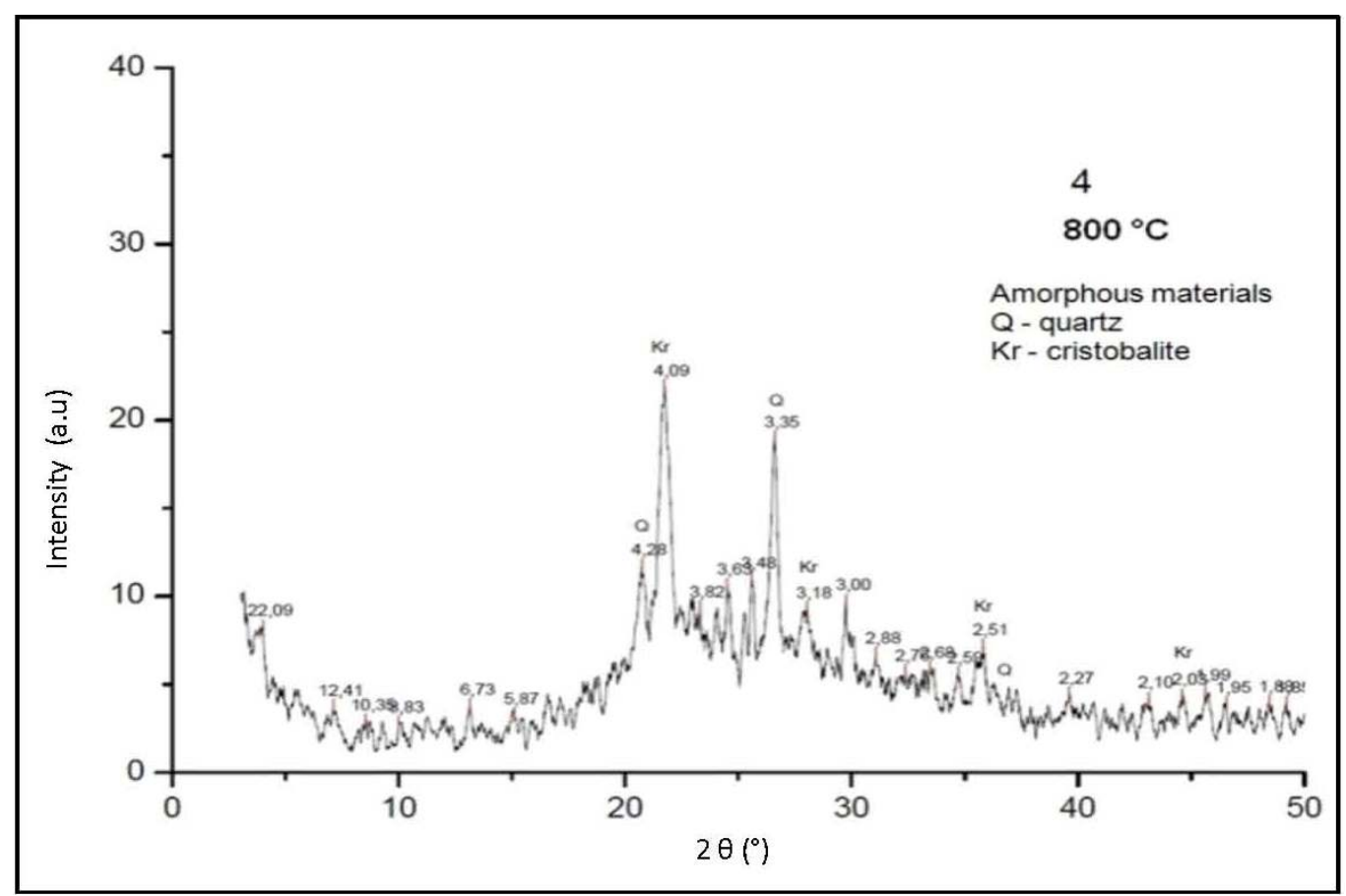

Figure 7. XRD diffractogram of the sample 4

Results of the analysis of SEM (Scanning Electron Microscopy) and EDS (Energy Dispersive Spectrometer) are shown in Figures 8, 9a, 9b, 10a, 10b and Tables 1 and 2. 


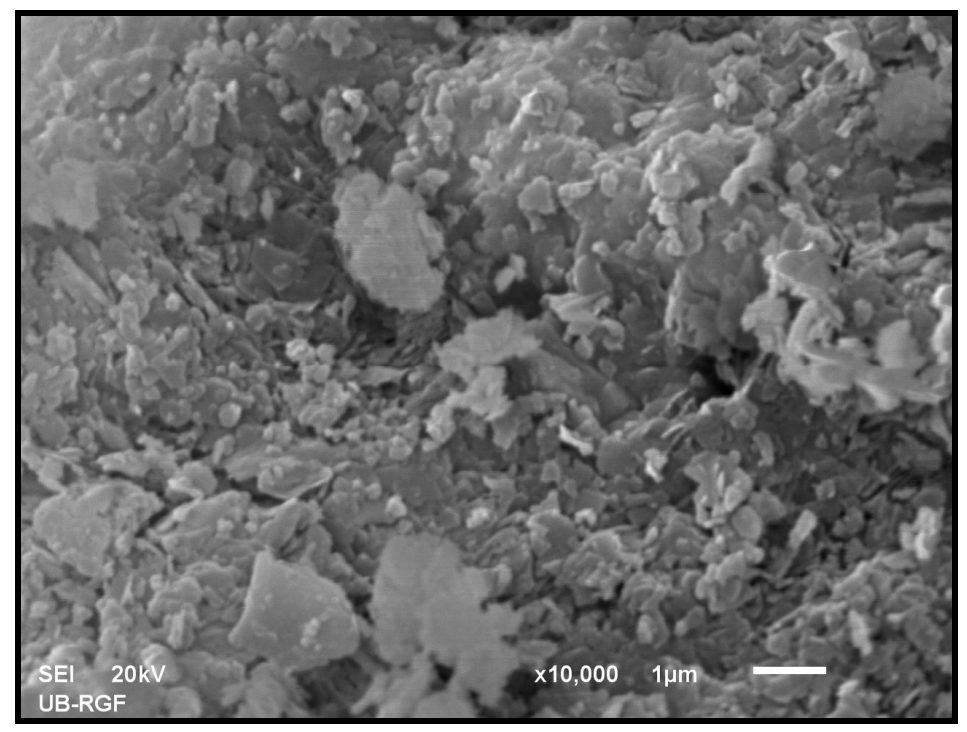

Figure 8. SEM microphotography (SEI) of the sample 1- initial premix

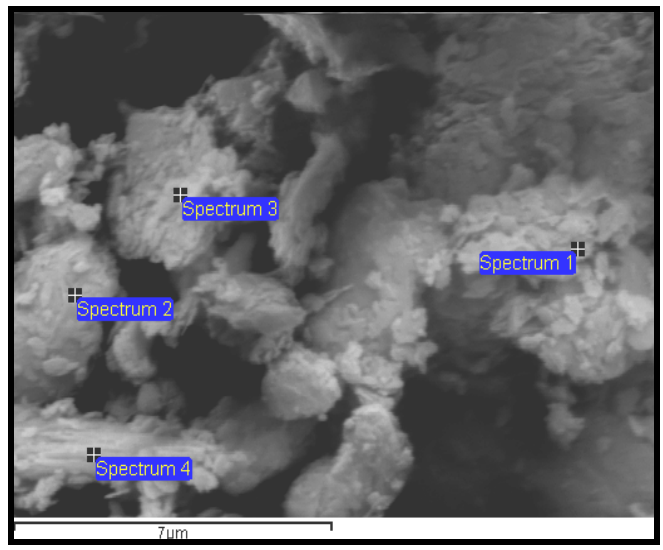

Figure 9a. SEM microphotography (SEI) of the sample 1- initial premix

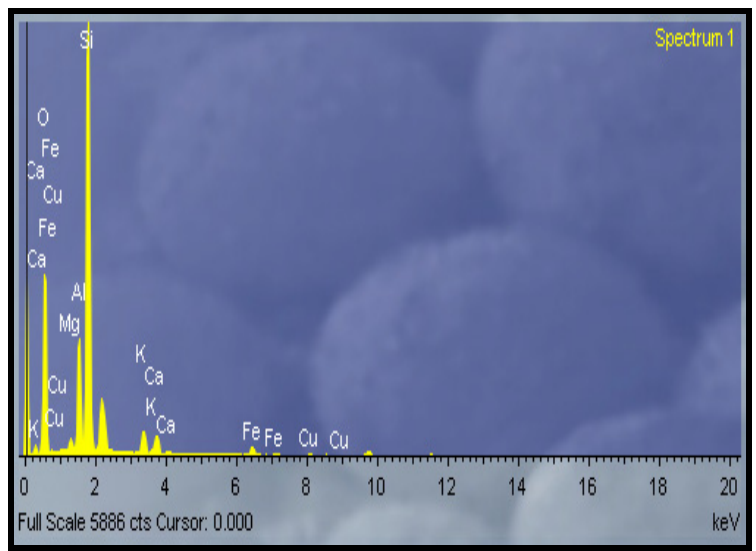

Figure 9b. Semi - quantitative microanalysis EDS) spectrum of point 1

Table 1. Chemical composition of point 1 on selected forms of sample 1

\begin{tabular}{cccccccc}
\hline \multicolumn{7}{c}{ Content (wt-\%) } \\
\hline $\mathrm{MgO}$ & $\mathrm{Al}_{2} \mathrm{O}_{3}$ & $\mathrm{SiO}_{2}$ & $\mathrm{~K}_{2} \mathrm{O}$ & $\mathrm{CaO}$ & $\mathrm{FeO}$ & $\mathrm{CuO}$ & $\mathrm{O}$ \\
0.80 & 7.71 & 34.03 & 3.10 & 2.38 & 2.57 & 0.75 & 48.66 \\
\hline
\end{tabular}

Chemical analysis of Point 1 in selected part of the Sample 1 (Table 1) and Spectrum of Point 1 (Figure 9b) clearly point the clinoptilolite mineral. 


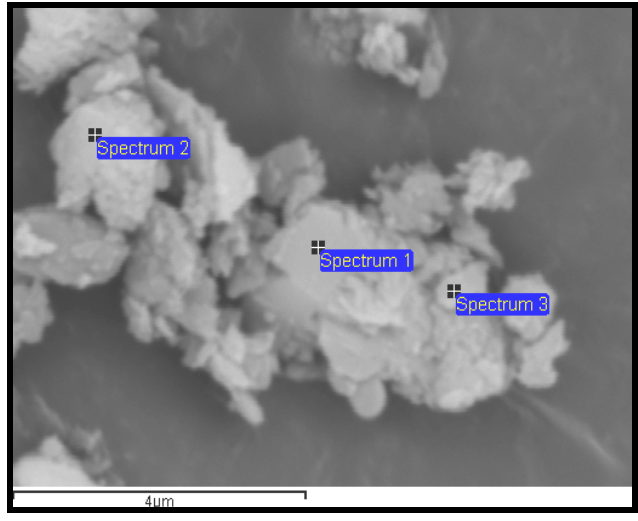

Figure 10a. SEM microphotography (SEI) of the sample 2

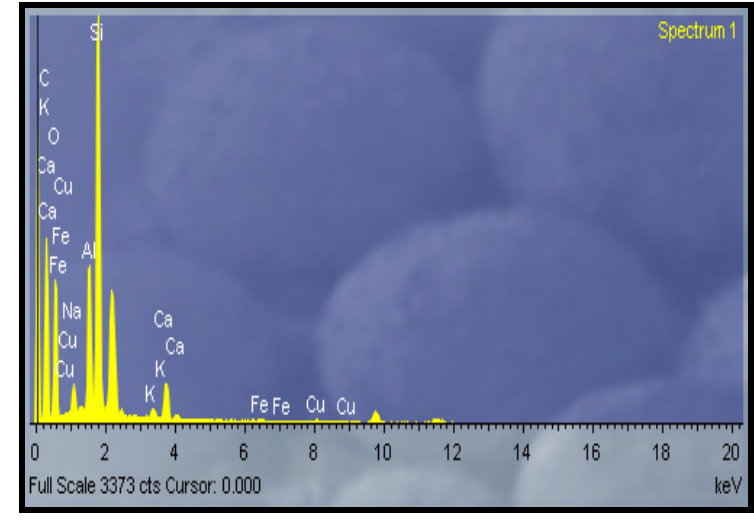

Figure 10b. Semi - quantitative microanalysis (EDS) spectrum of point 1

Table 2. Chemical composition of point 1 on selected forms of sample 2

\begin{tabular}{ccccccccc}
\hline \multicolumn{7}{c}{ Content (wt-\%) } \\
\hline $\mathrm{CO}_{2}$ & $\mathrm{Na}_{2} \mathrm{O}$ & $\mathrm{Al}_{2} \mathrm{O}_{3}$ & $\mathrm{SiO}_{2}$ & $\mathrm{~K}_{2} \mathrm{O}$ & $\mathrm{CaO}$ & $\mathrm{FeO}$ & $\mathrm{CuO}$ & $\mathrm{O}$ \\
21.90 & 0.80 & 2.19 & 5.86 & 0.21 & 0.92 & 0.15 & 0.23 & 67.75 \\
\hline
\end{tabular}

SEM micrographs (Figure 8, 9a and 10a) showed a dominant presence of Clinoptilolite mineral premix sample. Clinoptilolite appears in forms of small plates. This mineral together with Calcite, Quartz and Cristobalite is part of large granular aggregate. In addition to granular plate aggregates there were other forms of different size and morphology.

Chemical analysis of Point 1 in selected part of the Sample 2 (Table 2) and Spectrum of Point 1 (Figure 10b) clearly point the Calcite mineral.

\section{Conclusions}

Identification of minerals in foreign premix gives the possibility for better selection of minerals for domestic premix.

Mineral characterization of foreign premix identifies minerals in mineral part of premix. Those are Clinoptilolite (primary mineral), Quartz, Calcite and Cristobalite as secondary minerals.

Clinoptilolite belongs to zeolite group. Due to its' structure and good characteristics zeolites have wide application in different industries. Their usage in agriculture has shown huge benefits. Identification of Clinoptilolite as primary mineral in high quality foreign premix confirms necessity of better and comprehensive usage of mineral resources.

There are a few deposits of zeolite tuffs in Serbia. Modified clinoptilolite from one of our deposits is already being successfully utilized as an additive in livestock and poultry food. It is an imperative to utilize to its fullest extent zeolites from other deposits that are insufficiently exploited. Improvement of zeolite preparation will enable production of domestic premix.

\section{Acknowledgements}

This work is a part of investigation within the research Project-OI 176010: "Minerals Serbia: composition, structure, genesis, application, and the maintenance of environmental", financially supported by the Ministry for Science and Technology, Republic of Serbia.

\section{References}

Adamović, M., Tomašević-Canović, M., Milošević, S., Daković, A., \& Lemić, J. (2003). The Contribution of mineral adsorbents in the improvement performance of animal, health and quality of animal products. Biotechnology in Animal Husbandry, 19(5-6), 383-395.

Fray, K. (1981). The Encyclopedia of mineralogy. Hutchin.Ross Publi. Comp., Stroudsburg,Pennsylvania, 95. http://dx.doi.org/10.1016/S0033-3506(81)80117-5 
Ilić, M., \& Karamata, S. (1978). Specijalna mineralogija I deo, ing. Nikola Dončev, ICS, Balkanska 4/III, Beograd, 43-44.

Kerr, P. (1959). Optical mineralogy. New York: MC Graw Hill Book Comp. INC.

Kulikov, B., Zuev, V., Vainsenker, I., \& Mitenkov, G. (1985). Mineralogical handbook technologist-enrichment, Nedra, Leningrad, 174.

Ristić, P., \& Kovačević, R. (1983). Specijalna mineralogija, Tuzla, SNP, Novi Sad, 337.

Stojiljković, D., Josimov-Dundjerski, J., \& Rajić, M. (2002). Primena nekih mineralnih sirovina u savremenoj poljoprivredi. Letopis naucnih radova, 26(1), 86-92.

Vakanjac, B. (1992). Geologija ležišta nemetalnih mineralnih sirovina. Univerzitet u Beogradu, Rudarsko geološki fakultet Beograd, Posebno izdanje br.4.

Zivković, B., Migdal, W., Kosovac, O., Radović, C., \& Pejčić, S. (2010b). The effect of different pre-mixture in nutrition of fatteners. Biotechnology in Animal Husbendry, 26(5-6), 353-359. http://dx.doi.org/10.2298/BAH1006353Z

Zivković, B., Migdal, W., Kosovac, O., Radović, C., Delić, N., \& Pejčić S. (2010a). The effects of different pre-mixtures in nutrition of sows and piglets. Biotechnology in Animal Husbandry, 26(1-2), 47-55. http://dx.doi.org/10.2298/BAH1002047Z

Zlatić, H. (1983). Značaj i uloga premixa u ishrani stoke i proizvodnji stočne hrane. Krmiva, (1-2), 8-10.

\section{Copyrights}

Copyright for this article is retained by the author(s), with first publication rights granted to the journal.

This is an open-access article distributed under the terms and conditions of the Creative Commons Attribution license (http://creativecommons.org/licenses/by/3.0/). 